In recognition of Leicester Steven's contribution to its Research and Education responsibilities, the Earthquake Commission is instigating a Leicester Steven Lectureship at the School of Engineering, University of Canterbury.

In view of the Society's contribution to the engineering research, development and education interests of the EQC, Liecester Steven has always championed the Society's objectives and interests at Board level.

On the occasion of his retirement from the Board, it is therefore considered fitting that his unique contribution to the Society is recognised by the conferring of this special award.

\section{New Members.}

The following have recently been admitted as members of the Society:

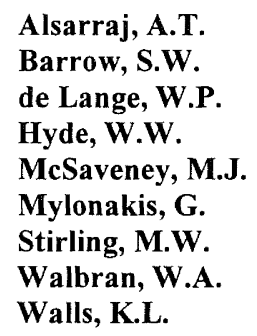

Alsarraj, A.T.

Barrow, S.W.

de Lange, W.P.

Hyde, W.W.

McSaveney, M.J.

Mylonakis, G.

Stirling, M.W.

Walbran, W.A.

Walls, K.L.

Formidable echo. Savarensky, F F, 3(3) pp107.

Technical note: Intensity of shaking generated by large shallow New Zealand earthquakes. Andrews, A L and Butcher, G W, 25(4) pp358.

The Haicheng, China, earthquake of February 1975: the first successfully predicted major earthquake. Adams, R D, 9(1) pp32.

\section{NZNSEE}

The reference to the NZNSEE study group for the seismic design of steel structures was omitted from this listing- as follows:

NZNSEE study group for the seismic design of steel structures. Section A: Analysis and design methods. Spring, K C F and Butcher, G W, 18(4) pp323.

Section B: Analysis and design methods. Patton, R N, 18(4) pp329.

Section C: Beam design. Walpole, W R and Butcher, G W, 18(4) $\mathrm{pp} 337$.

Section D: Column design. Butterworth, J W and Spring, K C F, 18(4) pp344.

Section E: Concentrically braced frames. Walpole, W R, 18(4) pp351.

Section F: Eccentrically braced frames. Sidwell, G K, 18(4) pp355.

Section G: Connection design. Nicholas, C J A, 18(4) pp360.

Section H: Beam-column joints. Walpole, W R, 18(4) pp369.

Section I: Composite design. Clifton, G C, 18(4) pp381.

Section J: Cold formed sections. Clifton, G C, 18(4) pp397.

Section K: Materials and workmanship. McKay, G R, 18(4) pp400.

It should be noted that the 30-year Index (1968-97) is available on the NZNSEE website.

\section{EARTHQUAKE ENGINEERING RESEARCH SCHOLARSHIPS}

The New Zealand National Society for Earthquake Engineering (NZNSEE) provides annual scholarships of up to $\$ 4000$ to suitably qualified persons to assist research activities related to earthquake engineering. Suitable research areas include most aspects of earthquakes and their effects. The total number of Scholarships awarded in any one year is at the discretion of the NZNSEE Management Committee. Applications are welcomed from individuals fulfilling the following criteria: 